\title{
Gêneros em práticas escolares de linguagens: currículo e formação do professor
}

\section{Genres in language practices at school: curriculum and teacher education}

Wagner Rodrigues Silva*

Universidade Federal do Tocantins

Palmas, Tocantins / Brasil.

RESUMO: O trabalho didático de recontextualização dos gêneros textuais para aulas de Língua Portuguesa, realizado por professores em formação inicial, em disciplinas de estágio supervisionado obrigatório da Licenciatura em Letras, é tomado como objeto de investigação. Focalizamos algumas tentativas de inovação de práticas de escrita propostas para alunos do Ensino Fundamental. Esta pesquisa está situada nos estudos indisciplinares da Linguística Aplicada e configura-se como um estudo de caso. Considerando a expressiva escolarização dos gêneros na escola, apresentamos uma unidade didática como instrumento orientador do planejamento pedagógico, o que foi realizado a partir de uma proposta sistêmico-funcional do circuito curricular baseado em gênero.

PALAVRAS-CHAVE: letramento; planejamento pedagógico; material didático.

ABSTRACT: The pedagogical work of recontextualizing textual genres for Portuguese Language classes, produced by trainee teachers, in mandatory disciplines of supervised pre-service teacher training in Language Teacher Education Courses, is taken as the object of investigation. We focus on some attempts for innovation concerning writing practices proposed to Elementary School students. This research is situated within the indisciplinary studies of Applied Linguistics and follows a case study design. Taking into account the significant schooling of genres at school, we present a teaching unit as a guiding tool for pedagogic planning, which has been developed from a SystemicFunctional Linguistics approach of genre-based curriculum cycle.

KEYWORDS: literacy; pedagogical planning; didactic material.

\footnotetext{
*wagnerodriguesilva@yahoo.com
} 
“o estágio supervisionado representa o nascimento do professor para essa profissão de valor inestimável para a formação do cidadão. É no estágio que o acadêmico coloca em prática a teoria que buscou nos períodos anteriores ao estágio". (Estágio I: 2012.2 - Introdução)

\section{Introdução}

Como reflexo da significativa produção do conhecimento científico nas ciências da linguagem, que, de alguma forma, é motivada por demandas sociais, as inovações relativas, especialmente, à seleção e ao planejamento didático de objetos e conteúdos de ensino, estão chegando às salas de aula da Educação Básica. Nesta investigação, concebo inovação a partir de Signorini $(2007)^{1}$ :

[A inovação é] compreendida como deslocamento ou reconfiguração dos modos rotineiros de raciocinar/agir/avaliar em questóes de estudo e de ensino da língua, reconfiguração essa impulsionada por demandas institucionais. [...] inovar é sempre uma qualificação positiva que favorece determinados agentes sociais em detrimento de outros, o que faz com que esteja sempre sujeita a contestação. Valem-se dela os agentes sociais, individuais e coletivos, para dar conta das contínuas demandas de adaptação e transformação de seus próprios contextos de atuação (SIGNORINI, 2007, p. 09).

De forma breve, concebo a Linguística Aplicada (doravante LA) como prática indisciplinar de investigação científica sobre usos situados das linguagens, especialmente considerando relações sociais assimétricas entre os atores sociais envolvidos no contexto investigado. Não me resta dúvida de que, realmente, como linguista aplicado, comprometo-me com colaboradores ou participantes das pesquisas por mim desenvolvidas.

\footnotetext{
${ }^{1}$ Esta pesquisa foi desenvolvida no grupo de pesquisa Práticas de Linguagens em Estágios Supervisionados - PLES (UFT/CNPq). Contribui para os projetos de pesquisa "Escrita reflexiva profissional nas licenciaturas: da gramática ao discurso" (CNPq n ${ }^{\circ}$ 407572/2013-9; PROPESQ/UFT no AG\#001/2014) e "Estudo gramatical-discursivo da escrita reflexiva profissional produzida por professores em formação inicial" (CNPq no 446235/2014-8). Texto apresentado na III Jornada de Multiletramentos, V Jornada de Popularização da Ciência e II Encontro de Produção Textual, UFSM, setembro de 2014.
} 
Portanto, preciso apresentar contribuições ou encaminhamentos para os problemas ou demandas sociais tomados como objeto de investigação.

Um exemplo de conhecimento científico que, nos últimos dez anos, vem contribuindo mais diretamente para o ensino de línguas, especialmente para o estudo da Língua Portuguesa como língua materna, disciplina sobre a qual me detive nesta pesquisa, são os gêneros textuais ou discursivos ${ }^{2}$. Dado o exposto, selecionei como objeto de investigação o trabalho didático de recontextualização dos gêneros para aulas de língua materna, o qual também é denominado de transposição didática (cf. CHEVALLARD, 2005; ROJO, 2013) ${ }^{3}$. Essa recontextualização dos gêneros para as aulas de língua traz implicaçôes diretas para as práticas escolares de linguagens - leitura/escuta textual, produção textual e análise linguística -, atividades organizadoras das aulas a serem planejadas pelo professor nas escolas de Educação Básica (BRASIL, 2006; 2000; 1998).

Ao assumir a identidade de linguista aplicado, situo-me num contexto investigativo bastante especial: o da formação inicial de professores em disciplinas de estágio supervisionado obrigatório das licenciaturas. Uma particularidade desse contexto é o fato de essas disciplinas se configurarem como portas de saída da universidade para os professores exercerem a docência na Educação Básica. Conforme afirmam os autores da epígrafe deste texto, por mim denominados de alunos-mestre, vinculados a uma Licenciatura em Letras - Língua Portuguesa, o estágio supervisionado representa o nascimento do professor para essa profissão de valor inestimável para a formação do cidadão ${ }^{4}$.

A denominação aluno-mestre é utilizada nas investigaçóes desenvolvidas no grupo de pesquisa Práticas de Linguagens em Estágios Supervisionados - PLES (UFT/CNPq), por mim coordenado. Referese sempre a alunos das licenciaturas, cursos superiores responsáveis pela

\footnotetext{
${ }^{2}$ Neste artigo, não me interessa fazer algum tipo de distinção teórica sobre as abordagens textual e discursiva dos gêneros. Para detalhes a respeito dessas abordagens, consultar Rojo (2005).

${ }^{3}$ Nos termos de Rojo (2013, p. 175), "a transposiçāo didática é o movimento pelo qual passamos do saber teórico (aquele que os cientistas e teóricos elaboram) para o saber a ensinar (planejamento e materiais didáticos) e, através deste, ao saber ensinado (aquele que realmente acontece em sala de aula)" (itálico do original).

${ }^{4}$ Todas as reproduções textuais dos relatórios de estágio foram feitas ipsis litteris, ou seja, não realizei alteração linguística alguma antes das reproduções dos excertos. Neste artigo, esses textos são reproduzidos em itálico.
} 
formação inicial de professores no contexto brasileiro (cf. SILVA, 2014a; 2013; 2012a; SILVA; DINIZ, 2014; MELO; GONÇALVES; SILVA, 2013; só para citar alguns).

Ao investigar o trabalho didático de recontextualização dos gêneros para aulas de língua materna, realizado por alunos-mestre, em disciplinas de estágio, delineio, além de novas demandas investigativas, algumas contribuições científicas da própria LA para a Educação Básica. Mais uma vez retomando a epígrafe, ressalto, de maneira pouco otimista com o excerto, que é no estágio que o acadêmico coloca em prática a teoria que buscou nos periodos anteriores ao estágio. Bom seria termos outras evidências, as de que a teoria e a prática já caminham reconciliadas ao longo de todo o percurso do aluno-mestre nas licenciaturas.

No segundo estágio supervisionado, realizado no semestre letivo subsequente ao do estágio atrelado à epígrafe deste artigo, os alunos-mestre, mais uma vez, deixaram transparecer uma formação profissional onde teoria e prática ainda caminham por vias distintas: Durante o estágio supervisionado em língua portuguesa e literatura II, nós acadêmicos do curso de Letras, tivemos a oportunidade de colocarmos em prática a teoria a qual fomos expostos durante os periodos anteriores. Essa experiência enriquece a nossa formação, pois é no estágio II que entramos em contato direto com a sala de aula (Estágio II: 2013.1: Considerações Finais).

Esta pesquisa se caracteriza como um estudo de caso, pois meu escopo de análise está restrito a três relatórios de estágio supervisionado, produzidos por uma mesma dupla de alunos-mestre nos três primeiros estágios supervisionados obrigatórios da Licenciatura em Letras - Língua Portuguesa ${ }^{5}$. A escolha realizada pelos alunos-mestre fora motivada pela opção de trabalhar com gêneros em turmas do $6^{\circ}$ Ano, nos dois últimos

\footnotetext{
${ }^{5}$ No Estágio Supervisionado I, devem ser observadas quinze (15) aulas; no Estágio Supervisionado II, devem ser observadas quatro (04) aulas e ministradas dezesseis (16); no Estágio Supervisionado III, devem ser observadas cinco (05) aulas e ministradas vinte e uma (21). Na rede estadual de ensino onde os estágios foram realizados, a duração da aula corresponde a 60 minutos. Nessas três disciplinas, os estágios devem ser realizados preferencialmente do Ensino Fundamental II. No primeiro semestre letivo de 2014, a dupla de alunos-mestre finalizou o quarto e último estágio da licenciatura, o qual possui a mesma carga horária que a disciplina anterior, havendo apenas a exigência do desenvolvimento preferencialmente das atividades no Ensino Médio. A licenciatura focalizada possui 08 (oito) períodos, os estágios são iniciados no meio do curso, ou seja, as quatro disciplinas mencionadas são ofertadas, respectivamente, nos $5^{\circ}, 6^{\circ}, 7^{\circ}$ e $8^{\circ}$ períodos.
} 
estágios realizados. Nesse sentido, os dois últimos relatórios foram por eles intitulados de "Os gêneros textuais no estágio supervisionado". Nas aulas de regência, fora implementado o projeto pedagógico "Leitores Ativos". Apesar do título, o referido projeto envolvia as três práticas escolares de linguagens; porém a ênfase fora dada às práticas de leitura e de produção textual. A escolha do projeto, nos termos utilizados pelos alunos-mestre, fora motivada pelo trabalho fragmentado de leitura e pelo reduzido vocabulário dos discentes, diagnosticados nas aulas durante o primeiro estágio realizado, quando eram observadas apenas as aulas dos professores colaboradores nas escolas de Educação Básica.

Além desta Introdução, das Consideraçôes finais, Referências e Anexo, este artigo está organizado em três partes principais. Em Aspectos teóricos: gênero e ensino, sintetizo algumas contribuiçōes teóricas dos estudos dos gêneros para o ensino de Língua Portuguesa na Educação Básica brasileira. Em Lingua (gem) como conteúdo de ensino, apresento, por meio de exemplificações dos dados focalizados, os resultados da investigação do trabalho de recontextualização do gênero como objeto de ensino para aulas de língua. Essa seção está subdividida em Leitura do texto ${ }^{\wedge}$ interpretação ${ }^{\wedge}$ produção escrita e Discussão sobre o gênero ${ }^{\wedge}$ produção escrita, cujos títulos identificam as principais etapas da sequência de atividades didáticas desenvolvida pelos alunos-mestre em torno do gênero selecionado como objeto de ensino. Por fim, em Encaminhamentos para o planejamento didático, apresento uma unidade didática como instrumento contextualizador do estudo do gênero na escola. A unidade didática é construída a partir de um segundo instrumento, denominado de circuito curricular mediado por gênero.

\section{Aspectos teóricos: gênero e ensino}

Nos estudos da linguagem, há diferentes abordagens teóricas dos gêneros, muitas das quais contribuíram para a elaboração de diretrizes curriculares produzidas por diferentes esferas governamentais (cf. SILVA, 2012b; 2012c; 2011; SILVA; MELO, 2009). Em outras palavras, estados e municípios produziram diretrizes curriculares em respostas às demandas locais das escolas de Educação Básica, sempre considerando as propostas curriculares nacionais como referência (BRASIL, 2006; 2002; 1998). Nessas últimas, há três conceitos teóricos básicos a serem considerados para a elaboração, seleção e planejamento de conteúdos a serem estudados em aulas de Língua Portuguesa, os quais, consequentemente, aparecem nos 
documentos oficiais derivados e informam programas de formação docente: gênero como objeto de ensino; texto como unidade de análise; e letramento como práticas sociais de escrita orientadoras do planejamento escolar.

$\mathrm{Na}$ abordagem discursiva, os estudos bakhtinianos, provavelmente, são os maiores influenciadores das diretrizes para o ensino. Fora bastante propagada, em instâncias formativas, a compreensão dos gêneros como "tipos relativamente estáveis de enunciados" (BAKHTIN, 2000, p. 280; itálico do original), característicos de diferentes esferas enunciativas. $\mathrm{Na}$ abordagem textual, destaco a noção de tipologia textual, propagada por Marcuschi (2008) como categoria auxiliar na descrição dos gêneros. Para o autor, gêneros são "textos materializados em situaçôes comunicativas recorrentes" (p. 155), ao passo que o tipo textual "designa uma espécie de construção teórica \{em geral uma sequência subjacente aos textos\} definida pela natureza linguística de sua composição \{aspectos lexicais, sintáticos, tempos verbais, relaçōes lógicas, estilo\}" (p. 154). Ainda, segundo Marcuschi (2008, p. 154), "em geral, os tipos textuais abrangem cerca de meia dúzia de categorias conhecidas como: narração, argumentação, exposição, descrição, injunção e diálogo".

Por trás das noções teóricas de gênero, texto e letramento, está o reconhecimento de que os usuários interagem em diversas situações da vida diária, características de distintos domínios sociais, a exemplo dos domínios jurídico e hospitalar, por meio da mediação de gêneros como o recurso jurídico e a guia de exame clínico, respectivamente. Conforme afirma Eggins $\left(2004\right.$, p. 56) ${ }^{6}$, numa abordagem sistêmico-funcional dos gêneros, "há muitos diferentes gêneros assim como há tipos de atividades sociais reconhecíveis em nossa cultura"

Na perspectiva-sistêmico funcional, os gêneros são concebidos como produtos dinâmicos das práticas interativas construídas culturalmente. Ou seja, "como certas combinações contextuais tornam-se estáveis, formas de interagir nesses contextos também se tornam habitualizadas e, eventualmente, institucionalizadas como gêneros" (EGGINS, 2004, p. $58)^{8}$. Saber utilizar gêneros pode facilitar o acesso do usuário a situaçôes

\footnotetext{
${ }^{6}$ Todas as traduções apresentadas neste artigo são de minha responsabilidade. 7 "there are as many different genres as there are recognizable social activity types in our culture" (EGGINS, 2004, p. 56).

8"as certain contextual combinations become stable, ways of interacting within
} 
interativas socialmente estabilizadas, mediadas por diferentes linguagens, logo, possuir o letramento para domínios sociais específicos, a exemplo do jornalístico, religioso, comercial, dentre inúmeros outros. Mais uma vez, utilizando-me das palavras da Eggins (2004, p. 74), saliento que "onde quer que a produção de linguagem seja utilizada para alcançar um propósito reconhecido culturalmente e estabilizado culturalmente, lá encontraremos um gênero"'.

Como os gêneros se realizam na materialidade textual, resta à escola também priorizar o texto como unidade de análise linguística, explicitando o funcionamento de elementos léxico-gramaticais característicos de gêneros específicos e, até mesmo, as estruturas textuais esquemáticas pelas quais são realizados os gêneros, considerando o dinamismo da linguagem e evitando o engessamento de formas linguísticas, que pode resultar na expressiva escolarização das atividades de linguagem. As escolhas linguísticas realizadas em textos pertencentes a gêneros são motivadas pelo contexto imediato da situação interativa, o qual, conforme já pontuamos, traz influências da cultura onde o gênero é produzido, portanto, esses objetos de ensino são instáveis, estão sujeitos às forças contextuais ${ }^{10}$.

Além de ser objeto de ensino, o gênero é concebido como meio ou espaço linguístico-discursivo para contextualizar o estudo da língua(gem). Essa última é recontextualizada como conteúdo disciplinar na escola. A exemplo das escolhas léxico-gramaticais realizadas espontaneamente pelo usuário, a partir de sistemas linguísticos de referência, a seleção de recursos linguísticos diversos é motivada por diferentes situaçôes interativas, configuradas em gêneros textuais, ou seja, em formas de interação características de uma dada cultura. Nessa perspectiva, idealizase a construção de um paradigma diferenciado para o ensino de língua portuguesa nas escolas brasileiras, contraposto à tradição do ensino nas escolas de Educação Básica (cf. SILVA, 2012b; 2012c; 2011).

Dado o exposto, numa perspectiva mais pragmática, da agência social

those contexts also become habitualized and, eventually institutionalized as genres" (EGGINS, 2004, p. 58).

9"Wherever language is being used to achieve a culturally recognized and culturally established purpose, there we will find genre" (EGGINS, 2004, p. 74).

${ }^{10}$ Neste artigo, não aprofundarei a abordagem dos gêneros textuais na Linguística Sistêmico-Funcional (LSF). Detalhes a respeito do assunto, o leitor pode encontrar em Silva (2014b) e Silva e Espindola (2013). 
pela linguagem, os gêneros podem ser concebidos nos seguintes termos postos por Bazerman (2006, p. 23):

Gêneros não são apenas formas. Gêneros são formas de vida, modos de ser. São frames para a ação social. São ambientes para a aprendizagem. São os lugares onde o sentido é construído. Os gêneros moldam os pensamentos que formamos e as comunicações através das quais interagimos. Gêneros são os lugares familiares para onde nos dirigimos para criar açôes comunicativas inteligíveis uns com os outros e são os modelos que utilizamos para explorar o não-familiar.

O trabalho pedagógico com a maior diversidade possível de gêneros é sugerido para as aulas de língua materna, lançando, especialmente para os professores, o desafio de evitarem que os gêneros sofram bruscas mutaçōes ao serem transformados em objeto de ensino no contexto escolar, resultando na excessiva escolarização da escrita ou no trabalho didático orientado essencialmente pela noção de texto (cf. SILVA, 2013b; 2012b; 2009a; 2009b).

Outro desafio a ser superado pela escola, o qual fora levantado por Street (2014) no âmbito dos novos estudos do letramento, seria a escola criar a falsa expectativa nos alunos, orientada por uma concepção autônoma de letramento ${ }^{11}$, ao estabelecer uma relação direta entre apropriação/ familiarização dos gêneros do poder, utilizados, pelos proprietários do letramento dominante, e empoderamento social, o que é proposto, especialmente, pelos estudos críticos do letramento no contexto acadêmico australiano ${ }^{12}$.

\footnotetext{
${ }^{11}$ Conforme Street (2014, p. 146), "o modelo autônomo de letramento tem sido um aspecto dominante da teoria educacional e desenvolvimental. Uma das razóes para nos referirmos a essa postura como modelo autônomo de letramento é que ela se representa a si mesma como se não fosse, de modo algum, uma postura ideologicamente situada, como se fosse simplesmente natural. Uma das razôes por que desejo chamar sua contrapartida de ideológico é precisamente para assinalar que aqui não estamos simplesmente falando de aspectos técnicos do processo escrito ou do processo oral. Estamos falando, sim, é de modelos e pressupostos concorrentes sobre os processos de leitura e escrita, que estão sempre encaixados em relaçōes de poder. A agenda, portanto, já está contestada. Existe variaçăo de letramento ao longo de toda uma gama de diferentes práticas, contextos e domínios, e em cada caso existem 'discursos concorrentes' (Lee, 1992)" (itálico adicionado).

${ }^{12}$ No âmbito da Linguística Sistêmico-Funcional (LSF), Martin (2012[1999], p. 225) defende que o principal objetivo do projeto desenvolvido no Programa de Escolas
} 
O empoderamento do cidadão não depende exclusivamente do acesso aos gêneros do poder, afinal, bens simbólicos de natureza diversa precisam ser partilhados de forma mais igualitária como conquistas sociais, não apenas os bens linguísticos ${ }^{13}$. Nas palavras de Street (2014),

Existem muitos gêneros de poder, não só um único letramento autônomo, e sabemos muito pouco sobre como eles operam - na Bolsa de Valores, por exemplo, ou nos patamares mais elevados do comércio e do governo. É possível especular que esses letramentos específicos, abreviados, por meio dos quais se comunicam aqueles que já detêm o poder, não são os mesmos gêneros trabalhados e explícitos ensinados na escola. Afinal, como tantos sabem, os próprios professores que ensinam esses gêneros não conseguem obter posições de poder em sua sociedade. Há muita pesquisa a ser feita ainda sobre as reais relações entre gêneros específicos e controle do poder, financeiro e político. Levar os alunos a acreditar que existe uma relação de mão única entre gêneros particulares ensinados na escola e aquelas posições de poder é prepará-los para a frustração e a desilusão. (STREET, 2014, p. 153-154)

A partir de uma pesquisa participante desenvolvida numa escola pública de Ensino Fundamental, categorizei as práticas de escrita na referida instituição em três tipos. Essas práticas são marcadas por uma abordagem didática formal dos gêneros no Ensino Fundamental (50 e $6^{\circ}$ Anos): tipos textuais como gêneros escolares; cópias textuais em modelos de gênero de referência; e formas escolarizadas de gênero de referência (SILVA, 2009a). Essas atividades de produção textual contrapõem-se a "uma visão social da escrita", os gêneros foram concebidos somente como formas textuais e não como formas de vida e de ação social (BAZERMAN, 2006, p. 19).

Desfavorecidas em Sydney consistia em "abrir o acesso aos gêneros, especialmente aqueles controlados por grupos privilegiados - com a fé (considerado ingênuo pelas críticas) que esta distribuição de recursos discursivos possa envolver recontextualizaçóes por grupos não privilegiados, os quais poderiam realinhar força" / "to open access to genres, especially those controlled by mainstream groups - with the faith (considered naive by critics) that this non-mainstream groups which would realign power".

${ }^{13}$ Conforme o Dicionário Paulo Freire, empoderamento é concebido como "um processo que emerge das interaçôes sociais em que nós, seres humanos, somos construídos e, à medida que, criticamente, problematizamos a realidade, vamos nos 'conscientizando', descobrindo brechas e ideologias; tal conscientização nos dá 'poder' para transformar as relaçôes sociais de dominação, poder esse que leva à liberdade e à libertação" (GUARESCHI, 2008, p. 166). 
Essas categorias revelam algumas mutações sofridas pelos gêneros ao serem transformados em objeto de ensino. A primeira, tipos textuais como gêneros escolares, talvez, tenha perdido força, mais recentemente, com a vulgarização do conhecimento linguístico entre os professores. Corresponde ao tratamento dos denominados tipos textuais, como narração, descrição e dissertação, enquanto gêneros tipicamente escolares, ou seja, os alunos são orientados a produzirem textos desses tipos simplesmente para cumprir uma atividade didática, cuja função pode se restringir à avaliação da versatilidade linguística do aluno.

A segunda categoria, cópias textuais em modelos de gênero de referência, revela a reprodução de uma prática bastante característica da escola. A estrutura textual esquemática característica do gênero ganha forma a partir da cópia do conteúdo de textos de referência e, nem sempre, o conteúdo reproduzido é adequado ao gênero imitado, ou seja, as determinações contextuais características do gênero estudado são ignoradas.

A terceira categoria, formas escolarizadas de gênero de referência, corresponde aos textos escritos em que os alunos produzem o texto a partir do modelo de gênero de referência, porém, a produção realizada não encontra interlocução autêntica na escola. Em outras palavras, a funcionalidade da produção escrita restringe-se ao próprio ato de produção e, talvez, de avaliação classificatória. Essa forma de escolarização também foi observada numa pesquisa por mim realizada previamente a partir de um álbum de gêneros textuais, proposto como produção escrita para uma turma do $1^{\circ}$ Ano do Ensino Médio (SILVA, 2012b).

Os excertos do Exemplo 1, reproduzidos adiante, ilustram as contribuições trazidas do trabalho didático com gênero para as aulas de Língua Portuguesa, conforme explicitado pela própria dupla de alunosmestre a partir da atividade de regência de aulas realizada por eles. As contribuições explicitadas estão inter-relacionadas. Não desconsiderando que os relatórios de estágio são instrumentos de avaliação do desempenho dos alunos-mestre na prática do estágio obrigatório da licenciatura, portanto, tendem a mostrar as experiências mais produtivas ao formador, os excertos revelam respostas ao trabalho didático desenvolvido pela professora colaboradora, cujas aulas foram observadas previamente pelos alunos-mestre. 
EXEMPLO 01

(A) $\mathrm{O}$ objetivo de nossas atividades com os gêneros textuais é colocar esses alunos em contato com a leitura para que os mesmos aprendam a gostar da leitura e levem isso para a vida inteira. (Estágio III: 2013.2 Referencial Teórico)

(B) O professor de língua materna pode valer-se dos gêneros textuais para desenvolver também o gosto do aluno para a leitura de diferentes tipos de textos, pois sabemos que a leitura desenvolve múltiplas capacidades no aluno. Cabe ao professor tornar a aula de leitura produtiva e convidativa, pois quando se trata de leitura temos que tornar esse momento rico em aprendizado. (Estágio II: 2013.1: Fundamentação Teórica)

(C) Através do trabalho com os gêneros textuais conseguimos desenvolver aulas interdisciplinares, em que usamos o gênero receita para abordarmos temas que fazem parte do dia a dia do aluno. Podemos perceber que a participação do aluno nessas aulas foi bem mais efetiva, pois em momentos como esse o aluno faz questão de expor o seu conhecimento prévio do assunto. (Estágio II: 2013.1: Fundamentação Teórica)

(D) Durante as atividades de leitura, interpretação e produção de texto no estágio supervisionado, nos empenhamos em sanar os problemas com a gramática que foram surgindo ao longo das produçóes de textos. O objetivo inicial das aulas ministradas estava voltado para o desenvolvimento do gosto pela leitura e competências linguísticas e discursivas dos alunos em questão. (Estágio II: 2013.1 - Fundamentação Teórica)

Nos excertos (A) e (B), os gêneros são representados como instrumentos capazes de contribuir para o desenvolvimento do gosto dos alunos pela leitura, o que pode acontecer pela socialização dos alunos com diferentes formas de manifestação do gênero. Os alunos-mestre parecem se esforçar para suprir a ausência da leitura diagnosticada ainda no primeiro estágio, quando aconteceu o contato inicial com turmas de $6^{\circ}$ Ano nas observações de aulas. Esse fato justificou a produção do projeto de leitura nos estágios de regência aqui focalizados. Porém, conforme dito no excerto (B), a produtividade das aulas de leitura está condicionada à capacidade do professor tornar a atividade de trabalho com a leitura produtiva e convidativa.

No excerto $(\mathrm{C})$, os gêneros são atrelados ao trabalho didático interdisciplinar, responsável pelo maior envolvimento dos alunos com a aula, pois, além do enfoque de assuntos do cotidiano de interesse dos discentes, eles trocam conhecimento com os professores em formação inicial, uma vez que os alunos expõem conhecimento prévio sobre o assunto. Sobre esse trabalho interdisciplinar, num outro momento de relato das aulas, os alunos-mestre afirmam que $o$ trabalho com o gênero receita também foi bem positivo, pois abordamos temas importantes como o desperdício de alimentos e alimentação saudável. Além da familiarização textual, as práticas sociais envolvendo gêneros são motivadas pela abordagem interdisciplinar assumida.

No excerto (D), o texto escrito pelo aluno motivou as escolhas do conteúdo gramatical trabalhado em aula, exatamente como no planejamento de aulas de Língua Portuguesa, proposto nos parâmetros curriculares 
nacionais vigentes para o trabalho didático com a referida disciplina escolar (cf. BRASIL, 1998; SILVA, 2012c; 2011). Ou seja, em algum momento, o aluno-mestre parece conseguir articular as práticas de leitura, escrita e análise linguística.

\section{Língua(gem) como conteúdo de ensino}

Conforme exposto na seção anterior, a relação entre texto, contexto e gênero é bastante estreita na LSF. Essa relação auxilia-nos a compreender o processo de recontextualização do gênero no domínio escolar, quando o gênero é tomado como objeto de ensino e ambiente para aprendizagem da língua(gem). Nessa perspectiva, "a teoria dos gêneros sugere que textos que fazem diferentes trabalhos na cultura irão se revelar em diferentes formas, operando através de diferentes estágios ou etapas" (EGGINS; MARTIN, 1997, p. 236 ${ }^{14}$. O contexto de cultura exerce interferência direta nas funções sociais e na configuração do gênero, a qual se realiza em textos.

De acordo com Eggins e Martin (1997, p. 236), numa dada situação comunicativa, a interferência contextual no texto, concebido como materialização de um gênero, é probabilística e não determinística. Dependendo da maneira como o gênero é mobilizado do seu contexto original para a sala de aula, transformações significativas do ponto de vista formal e funcional podem acontecer, resultando na escolarização da escrita ou no que denomino de recontextualização improdutiva do gênero, ou seja, ele sofre mutações formais e funcionais.

No Exemplo 02, reproduzo o cronograma de gêneros textuais e de atividades do projeto aplicado pelos alunos-mestre nos dois estágios de regência focalizados nesta pesquisa (negrito do projeto original). Ao analisar o cronograma, chamam-me a atenção dois fatos, os quais interferem diretamente no processo didático de recontextualização dos gêneros selecionados para as aulas de Língua Portuguesa: (1) a quantidade de gêneros selecionados; e (2) a sequência recorrente das atividades didáticas planejadas em torno dos diferentes gêneros, tomados como objeto de ensino isoladamente.

\footnotetext{
${ }_{14}$ "Genre theory suggests that texts which are doing different Jobs in the culture will unfold in different ways, working through different stages or steps" (EGGINS; MARTING, 1997, p. 236).
} 


\begin{tabular}{|c|c|c|}
\hline \multicolumn{3}{|c|}{ EXEMPLO 02} \\
\hline AULA & $\begin{array}{l}\text { GENERO } \\
\text { TEXTUAL }\end{array}$ & ATIVIDADE \\
\hline $1^{\circ}$ & Fábula & $\begin{array}{l}\text { Leitura, interpretação e construção da moral da } \\
\text { historia. Fábula o Leão e o Ratinho }\end{array}$ \\
\hline $2^{o}$ & Conto & $\begin{array}{l}\text { Leitura, interpretação, produção de texto e } \\
\text { discussão sobre animais em extinção. Conto } \\
\text { Procura-se. }\end{array}$ \\
\hline $3^{\circ}$ & Poema & $\begin{array}{l}\text { Leitura, interpretação de texto e recital na sala } \\
\text { de aula. }\end{array}$ \\
\hline $4^{\circ}$ & Música & $\begin{array}{l}\text { Leitura, canto, interpretação e ilustração da } \\
\text { música Aquarela. }\end{array}$ \\
\hline $5^{\circ}$ & Entrevista & $\begin{array}{l}\text { Discussão sobre o gênero e realização de uma } \\
\text { entrevista com os colegas. }\end{array}$ \\
\hline $6^{\circ}$ & Carta & $\begin{array}{l}\text { Discussão sobre o gênero, leitura e produção } \\
\text { de texto. }\end{array}$ \\
\hline $7^{\circ}$ & E-mail & $\begin{array}{l}\text { Socialização do conhecimento prévio e } \\
\text { experiências da turma a cerca do gênero. }\end{array}$ \\
\hline $8^{\circ}$ & Propaganda & $\begin{array}{l}\text { Socialização do conhecimento prévio do aluno, } \\
\text { exibição de slides sobre o gênero. }\end{array}$ \\
\hline 90 & Receita & $\begin{array}{l}\text { Construção do conceito junto à turma, } \\
\text { exposição de slides com dados sobre desperdício } \\
\text { de alimentos no Brasil e exposição de receitas } \\
\text { inteligentes que visam reaproveitar alimentos. }\end{array}$ \\
\hline $10^{\circ}$ & Notícia & $\begin{array}{l}\text { Construção do conceito junto à turma, exposição } \\
\text { de slides com particularidades do gênero, leitura } \\
\text { de uma notícia impressa e produção de texto. }\end{array}$ \\
\hline
\end{tabular}

(Estágio I e II: Projeto: Leitores Ativos - Cronograma).

Nos Estágios II e III, devem ser ministradas dezesseis (16) e vinte e uma (21) aulas, respectivamente, pelos alunos-mestre, conforme expliquei em nota de final de página na introdução deste artigo. No primeiro, todas as aulas foram ministradas numa única turma do $6^{\circ}$ Ano, ao passo que, no segundo, as aulas foram ministradas em duas turmas. Provavelmente, todos os gêneros não foram trabalhados nos estágios, pois, contrariando essa hipótese, trabalhar-se-ia um gênero por aula, o que seria impossível em 1 hora de aula. A análise dos planos de aula revela o trabalho de alguns gêneros em até três aulas consecutivas, considerando que a totalidade do tempo da aula nem sempre é aproveitada em função do planejamento realizado, ações ou fatos intempestivos se instauram.

Dos dez (10) gêneros selecionados, sete (07) seguem, explicitamente, sequências de atividades didáticas semelhantes de planejamento para 
efetivação do trabalho em sala de aula: leitura do texto $\wedge$ interpretação $\wedge$ produção escrita ou discussão sobre o gênero ${ }^{\wedge}$ produção escrita. As exceções a essas sequências são os gêneros e-mail, propaganda e receita, para os quais, no planejamento, não há atividades de produção textual. Todas as sequências de atividades reproduzem uma prática pedagógica da cultura escolar, onde o professor exemplifica um conteúdo, propóe exercícios para fixação e, por fim, solicita alguma produção tomando como referência o conteúdo exemplificado inicialmente.

A análise dos dados revela que, na realidade, os alunos não são levados a interagir a partir dos gêneros, mas a realizarem um trabalho metalinguístico sobre os objetos de ensino. Uma forte evidência desse fato é a primeira aula ministrada em cada turma. No plano de aula, são apresentados os seguintes objetivos de aula: (1) Estimular o gosto do aluno pela leitura não apenas na sala de aula, mas na vida cotidiana; e (2) Levar os alunos a conhecerem o que é gênero textual, qual sua função e onde podemos encontra-los. O segundo objetivo dificilmente permitirá que se alcance o primeiro, ainda que, por não ser uma prática comum em muitas aulas de Língua Portuguesa, a novidade da diversidade de gêneros possa motivar a participação dos alunos nas atividades propostas.

Os alunos-mestre parecem atentos à importância do trabalho de contextualização do gênero selecionado na vida cotidiana, o que não foi evidenciado apenas nos objetivos expostos previamente, mas também nos seguintes excertos das sequências de atividades didáticas reproduzidas a partir do cronograma no Exemplo 02: Discussão sobre o gênero (entrevista); Discussão sobre o gênero (carta); exibição de slides sobre o gênero (propaganda); e exposição de slides com particularidades do gênero (notícias). Minha leitura crítica do projeto pedagógico implementado mostra que esse instrumento didático pode possibilitar apenas o reconhecimento de certo número de gêneros e, em alguns momentos, oportunizar ao aluno a produção textual a partir de um modelo de texto pouco contextualizado.

No Exemplo 03, está mais evidente o esforço para que aspectos funcionais do gênero e, consequentemente, do contexto social de circulação do objeto de ensino, fossem focalizados. Para tanto, os alunos-mestre precisaram utilizar recursos tecnológicos disponíveis na escola para que a exemplificação fosse a mais autêntica possível, fugindo, de alguma forma, da dinâmica mais comum das aulas na rede pública de ensino focalizada (o grande apoio dos recursos tecnológicos da escola, como, disponibilidade do laboratório de informática e o uso dos kits-multimídias para atividades em sala de aula). 
EXEMPLO 03

Durante a realização de nossas atividades na escola campo, tivemos sempre o grande apoio dos recursos tecnológicos da escola, como, disponibilidade do laboratório de informática e o uso dos kits-multimídias para atividades em sala de aula. Quando exibimos a entrevista com a presidente Dilma Roussef, buscamos aproveitar ao máximo os meios tecnológicos presentes na sala de aula, procuramos mostrar mais que simples slides com conceitos e fragmentos de entrevista, assim, o aluno pode valer-se dessa informação para construir o seu conhecimento acerca do gênero. (Estágio III: 2013.2 - Referencial Teórico)

O trabalho didático com gêneros pode contribuir para o empoderamento do aluno, quando atividades didáticas cooperam de forma sustentável para familiarização do aprendiz com atividades de linguagem tomadas como referências a partir de domínios sociais diversos. Ou seja, essas atividades podem servir como modelos para outras atividades de linguagem, realizadas por meio de diferentes gêneros textuais em diversos domínios sociais, haja vista que o quantitativo de gêneros lembrados no espaço escolar é limitado. O empoderamento do aluno também está atrelado ao fortalecimento do letramento linguístico do aluno, permitindo ao usuário o desenvolvimento de atividades de reflexão sobre o funcionamento da língua(gem). Em outras palavras, o referido letramento é responsável pela conscientização crítica do funcionamento da língua(gem) pelo aprendiz ${ }^{15}$.

Dado o Exemplo 03, além de recursos tecnológicos, que instrumentos didáticos podem contribuir para um planejamento pedagógico que, realmente, considere a necessidade do empoderamento discente? $\mathrm{Na}$ LA, os projetos de letramento são propostos como um instrumento didático desencadeador do empoderamento do aprendiz. De fato, podem funcionar como gêneros catalisadores ${ }^{16}$ de saberes e práticas para o estudo dos gêneros

\footnotetext{
${ }^{15}$ Neste artigo, não me deterei à abordagem sistêmico-funcional de ensino e aprendizagem da língua(gem) e sobre a língua(gem). Esclarecimentos a respeito dessa abordagem podem ser vistos em Christie (2006) e Silva et al (2015).

${ }^{16}$ De acordo com Signorini (2006, p. 8), gêneros catalisadores favorecem "o desencadeamento e a potencialização de açôes e atitudes consideradas mais produtivas para o processo de formação, tanto do professor quanto de seus aprendizes. (...) tais gêneros assumem a função de locus desse processo em fluxo, não necessariamente a função de objeto ou alvo desse mesmo processo. Locus no sentido de um espaço regulado de natureza linguístico-discursiva e também sociocognitiva, feito de trilhos e andaimes indispensáveis à construção do novo: novos gêneros feitos da mistura ou entrelaçamento de outros já conhecidos; novos textos visando interlocutores e novas indagaçóes, mas ancorados na experiência com gêneros e práticas bem conhecidas, inclusive escolares; novos objetos de ensino orientados por novas concepçôes e novos
} 
na escola básica, evitando o trabalho pouco contextualizado de gêneros integrantes de listas de objetos de ensino para aulas de língua, conforme revela a pesquisa apresentada neste artigo. Mas o que são projetos de letramento? De acordo com Kleiman (2000, p. 238),

para construir novas funções para a escrita, e a partir daí ensinar os tipos de textos que preenchem essas funções, os projetos de letramento são essenciais. Por projeto de letramento entendemos um conjunto de atividades que se origina de um interesse real na vida dos alunos, e cuja realização envolve o uso da escrita, isto é, a leitura de textos que, de fato, circulam na sociedade e a produção de textos que serão lidos, em um trabalho coletivo de alunos e professor, cada um segundo sua capacidade. O projeto de letramento é uma prática social em que a escrita é utilizada para atingir algum outro fim, que vai além da mera aprendizagem da escrita (aprendizagem dos aspectos formais apenas), transformando objetivos circulares como "escrever para aprender a escrever" e "ler para aprender a ler" em ler e escrever para compreender e aprender aquilo que for relevante para o desenvolvimento e realização do projeto.

Conforme destacam Oliveira et al. (2011), a prática de projetos não é uma novidade didática, porém há diferentes tipos de instrumentos didáticos com denominações semelhantes, a exemplo do projeto investigado neste artigo. As autoras destacam ainda que não depende dos projetos de letramento a resolução dos "problemas de exclusão e insucesso escolar na área de linguagem” (OLIVEIRA et al., 2011, p. 13). A complexidade do ensino de língua envolve minimamente aspectos políticos, econômicos, sociais, culturais, além de questôes ligadas diretamente à educação e aos estudos da linguagem. Os projetos de letramento são bastante desafiadores e, por se originarem de interesses reais na vida dos alunos, requerem bastante envolvimento da comunidade escolar, sendo demandada inclusive uma prática pedagógica interdisciplinar.

Em síntese, sobre a demanda da interdisciplinaridade, as licenciaturas precisam ter seus currículos revistos a fim de preparar os professores egressos para assumirem uma atitude, até mesmo, indisciplinar no local de trabalho, possibilitando trocas e construçóes de saberes entre os educadores. Essa disposição ao diálogo e à cooperação ainda parece estranha aos próprios formadores em universidades brasileiras.

objetivos, mas articulados em sequências de atividades que se integram a práticas de ensino já existentes" (itálico do original). 


\subsection{Leitura do texto ^ interpretação ^ produção escrita}

No Exemplo 04, reproduzo o relato da sequência de atividades didáticas que focalizou o conto como objeto de ensino, conforme denominação utilizada para o gênero pelos alunos-mestre, bem como a produção textual escrita resultante. Nos dois exemplos seguintes, utilizo numerais ordinais para identificar as sequências de atividade mencionadas. No Exemplo 04, a sequência resultou na produção escrita de um texto do mesmo gênero. Assim como realizados com os demais gêneros selecionados, o primeiro momento da aula foi dedicado, conforme plano de aula, a Conceituar o gênero conto juntamente com a turma, utilizando o seu conhecimento prévio através de diálogo com a mesma.

Infelizmente, mesmo enfatizando classificação e caracterização do gênero, houve um equívoco na identificação do texto selecionado para leitura. O texto "Procura-se" (ver anexo deste artigo), publicado originalmente na revista Ciência hoje para crianças, corresponde a uma matéria educativa, na qual são descritos os hábitos dos beija-flores ou colibris, dando-se ênfase à espécie brasileira Balança-Rabo-Canela. O último parágrafo do texto se sobressai por informar sobre as causas da extinção da ave, daí o caráter educativo característico, inclusive da revista em que fora publicado ${ }^{17}$.

\begin{tabular}{|l|}
\hline Exemplo 04 \\
\hline ( $\left.1^{\circ}\right)$ O primeiro gênero textual que trabalhamos foi o conto, em que trabalhamos o conto "Procura-se". \\
Iniciamos a aula construindo o conceito juntamente com a turma, $\left(2^{\circ}\right)$ após esse momento dispomos à turma \\
o conto em texto impresso, para uma leitura silenciosa. Como o conto tratava da historia de um beija-flor em \\
extinção, isso chamou a atenção dos alunos para o texto, aproveitamos que o texto foi bem recebido pela turma \\
e ( $\left.3^{\circ}\right)$ nos aprofundamos nas discussóes. \\
$\left(4^{\circ}\right)$ Em outro momento da aula levamos para a sala, dados sobre animais que estão em extinção no Brasil, e \\
as causas que levaram esses animais a entrarem para essa estatística. Expomos no quadro branco uma pequena \\
lista com os nomes desses animais e $\left(5^{\circ}\right)$ solicitamos que a turma produzisse um conto sobre um deles baseado \\
no que haviam aprendido sobre o gênero e $\left(6^{\circ}\right)$ em seguida ilustrasse com o desenho do animal da sua escolha. \\
(Estágio II: 2013.1 - Relato das Aulas)
\end{tabular}

${ }^{17}$ Optei por identificar o texto como do gênero matéria tomando como referência a definição apresentada por Costa (2008, p. 132) no Dicionário de gêneros textuais. Para o autor, "matéria é tudo aquilo de que se trata, ou seja, um assunto, expresso por escrito ou oralmente, como o teor de um debate, o material de uma pesquisa, etc. Nesse sentido, passa a ser um termo muito geral. Interessa-nos aqui destacar matéria como gênero textual do discurso jornalístico (falado, escrito, televisivo, internético) que pode ser referir a qualquer texto jornalístico, ou especificamente a uma notícia, ou ainda a matéria de propaganda que, paga por anunciantes, se assemelha a um texto jornalístico, mas distingue-se deste por receber tratamento multissemiótico especial”. 


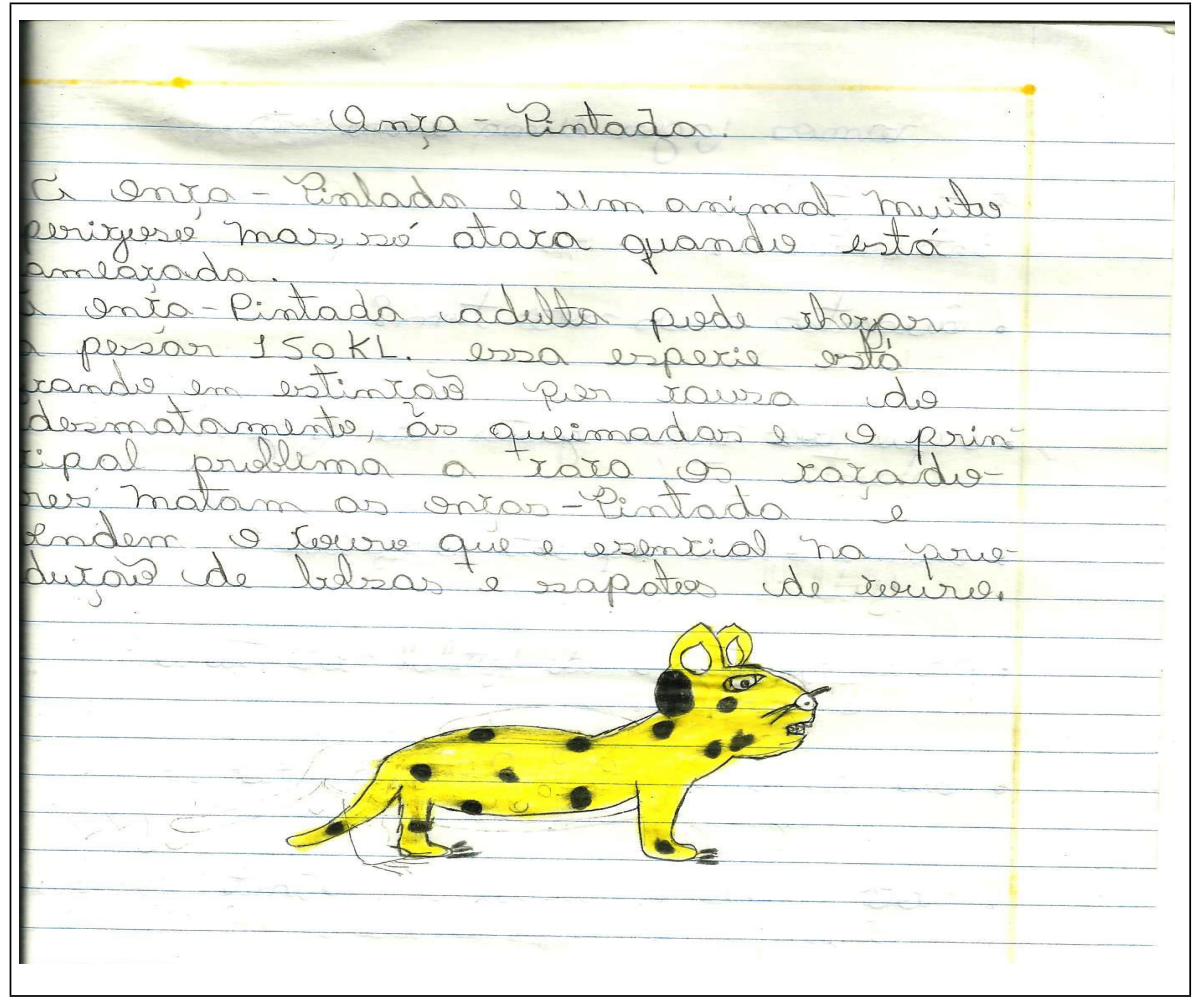

No Exemplo 04, identifiquei as etapas da sequência de atividades didáticas realizadas. No primeiro momento, é realizado o trabalho metalinguístico sobre o gênero, ainda que classificado de forma equivocada ${ }^{18}$. No segundo momento, o texto é entregue à turma para atividade de leitura silenciosa, a qual, no terceiro momento, é dada continuidade com a discussão aprofundada sobre o assunto. No quarto momento, é realizada

\footnotetext{
${ }^{18}$ Conforme o Dicionário de gêneros textuais, o conto, "assim como a novela e o romance são do tipo narrativo, assim também o conto literário o é. Em contraste com o romance, que geralmente é mais longo, o conto é mais curto (short story, no inglês), isto é, de configuração material narrativa pouco extensa, historicamente verificável. Essa característica de síntese traz outras: (i) número reduzido de personagem ou tipos; (ii) esquema temporal e ambiental econômico, muitas vezes, restrito; (iii) uma ou poucas ações, concentrando os eventos e não permitindo intrigas secundárias como o no romance ou na novela, e (iv) uma unidade de técnica e de tom (fracção dramática, sedutora, em que tempo, espaço e personagem se fundem, muitas vezes) que o romance não mantém" (COSTA, 2008, p. 67; itálico do original)
} 
uma abordagem interdisciplinar, pois a temática do meio ambiente, mais precisamente a extinção de algumas espécies de animais, foi trabalhada em sala de aula. Conforme visto na segunda seção deste artigo, os alunos-mestre pontuaram a abordagem interdisciplinar como uma das vantagens do trabalho com gênero. No quinto momento, é solicitada aos alunos a produção de um texto do mesmo gênero sobre um dos animais em extinção, apresentados pela dupla de estagiários. No sexto momento, o enfoque ainda é na produção textual, pois foi solicitado que os alunos ilustrassem os textos produzidos, os quais foram, posteriormente, socializados entre os alunos da própria turma. A atividade de ilustração das produçôes escritas é bastante característica das práticas de letramento escolar, o que tem início ainda na educação infantil.

Não há evidências no relatório de que a produção escrita reproduzida no Exemplo 04 tenha passado por alguma reescrita, ou seja, a atividade parece cumprir a função maior do encerramento de um ciclo da sequência de atividades didáticas em torno de um gênero. Se a produção textual fosse tomada como processo, uma oportunidade para se realizar uma atividade de reflexão sobre a própria escrita, a reescrita deveria ser encaminhada. A conexão de orações e, consequentemente, o trabalho com o uso de mecanismos coesivos, incluindo a pontuação, seriam aspectos do texto que poderiam ser focalizados na reescrita.

Conforme o texto apresentado como modelo, inicialmente, o aluno caracteriza o animal focalizado, o que acontece nos dois primeiros períodos. Posteriormente, o aluno escreve sobre as causas da extinção da onça-pintada. É provável que o conteúdo do texto seja uma reprodução das informações trazidas pelos alunos-mestre, pois não houve pesquisa realizada pelos discentes, o que poderia contribuir para o aprofundamento da discussão sobre o assunto e para uma prática de escrita mais próxima à dos jornalistas, que precisam realizar pesquisas em fontes diversas para produzirem suas matérias.

\subsection{Discussão sobre o gênero ^ produção escrita}

Finalmente, o Exemplo 05 ilustra a sequência de atividades didáticas em que a atividade metalinguística sobre o gênero é seguida pela prática de produção textual. $\mathrm{O}$ trabalho escolar em torno da propaganda não inclui a produção escrita no cronograma reproduzido no Exemplo 02, porém, as etapas identificadas no relato reproduzido adiante trazem a produção da propaganda pelos alunos como o encerramento do ciclo de trabalho sobre o gênero selecionado. 


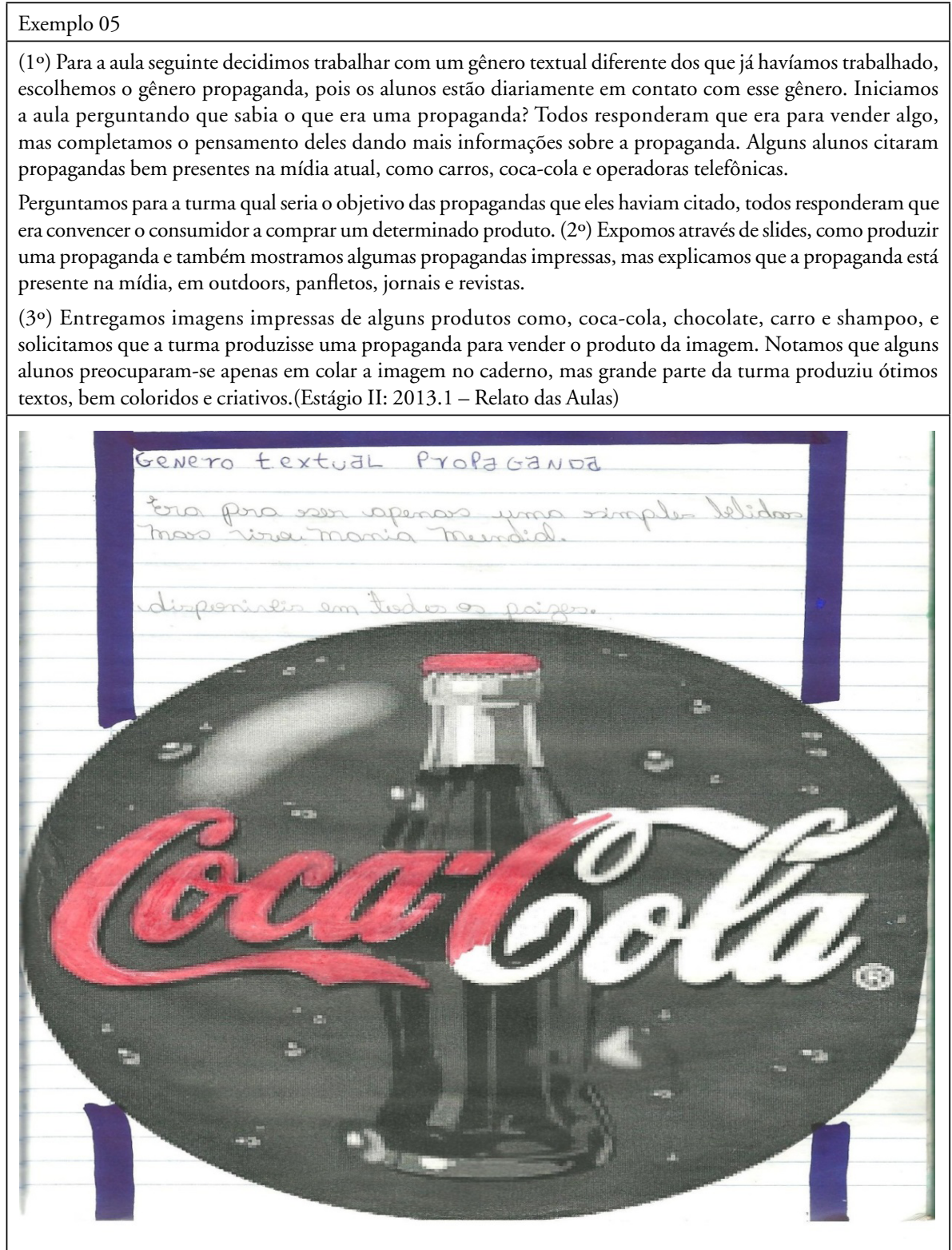

O primeiro momento da sequência de atividades em torno da propaganda é marcado pela descrição coletiva do gênero, quando os alunosmestre questionam os discentes a respeito do conhecimento de mundo que 
eles possuem sobre a propaganda, o que é um tipo de procedimento bastante recomendado na universidade. Funçóes e exemplos de propagandas foram mencionados pelos discentes. $\mathrm{O}$ segundo momento foi caracterizado pela exposição descritiva do gênero de forma mais sistemática, seguida de algumas exemplificaçōes com ênfase em textos impressos, o que fora realizado com o projetor eletrônico como recurso tecnológico. $\mathrm{O}$ ciclo de atividades se encerra com a produção textual a partir de imagens impressas de marcas famosas disponibilizadas pela dupla de estagiários. A partir dos impressos, os alunos produziram textos no próprio caderno.

Da mesma forma como observado no Exemplo 04, o texto reproduzido no Exemplo 05 evidencia que o objetivo da sequência de atividades parece se restringir ao domínio de aspectos formais, pois as próprias funções genéricas focalizadas previamente perdem a relevância ao se produzir uma réplica de propaganda num caderno escolar. $\mathrm{O}$ caráter multissemiótico do gênero é explorado no texto produzido, pois a ênfase é dada à logomarca do produto, respeitadas as cores da marca, colada e pintada sobre a folha do caderno, onde também se sobressaem as linhas das folhas pautadas. Ou seja, o produto anunciado é sobreposto às marcas da cultura escolar. Uma espécie de moldura azulada parece ser utilizada para prender a atenção do leitor sobre o produto. A moldura pode auxiliar a desviar a atenção do leitor (ou dos próprios alunos-mestre, avaliadores direto do texto) dos traços contextuais trazidos pelo suporte escolar utilizado, mesmo que, por outra perspectiva, o traçado também possa ser lido como indício de uma prática escolar.

Como nas verdadeiras propagadas impressas do cotidiano, os alunos utilizam minimamente a linguagem verbal (Era pra ser apenas uma simples belidas mas virou mania mundial. Disponiveis em todos os paizes.), mesmo que o público alvo da propagada produzida não esteja bem definido. O leitor do trabalho escolar pode se perguntar onde circularia uma peça publicitária desse tipo, a qual faz referência à presença do produto em todos os países do mundo. Essa pergunta provoca um segundo questionamento: quem seria o público alvo da propaganda? Esses questionamentos seriam evitados se os alunos fossem provocados a produzir textos com funções sociais mais claras, dentro de situações de aprendizagem bem definidas, diferentemente do simples exercício da escrita escolar descontextualizada. 


\section{Encaminhamentos para o planejamento didático}

Para finalizar este artigo, apresento um encaminhamento prático para o planejamento de aulas de língua, possibilitando uma contextualização mais ampla das práticas escolares de linguagens - leitura/escuta textual, produção textual e análise linguística. Este encaminhamento vem sendo construído a partir do meu percurso de pesquisa indisciplinar na LA, com meus orientandos de pós-graduação, na modalidade acadêmica e, principalmente, na profissional (BEZERRA, 2015; GARCIA, 2015; MONTEIRO, 2015; SILVA et al., 2015). Tenho proposto a elaboração de unidades didáticas como alternativas aos projetos de letramento, os quais, apesar da significativa produtividade e relevância social, ainda demandam esforços de difícil operacionalização em muitas escolas brasileiras. Essas unidades também não se caracterizam como um instrumento de ensino completamente inovador para responder aos desafios da educação linguística, em especial o estudo da Língua Portuguesa, disciplina a que me detive mais diretamente nesta investigação científica.

Por unidade didática, compreendo uma sequência de atividades didáticas organizadas a partir da articulação das diferentes práticas escolares de linguagens, em função do trabalho escolar com um número de gêneros selecionados como objetos de ensino, o que também pressupóe o uso do gênero como locus de contextualização para o estudo da língua(gem). A unidade didática funciona como um suporte onde o professor pode organizar as atividades de ensino em função da elaboração de um produto final coletivo, o qual pode ser um gênero textual produzido pelos alunos. Ou seja, as atividades didáticas configuradoras das práticas escolares de linguagens são desenvolvidas como etapas da produção do produto final.

Na Figura 1, apresento as funções didáticas exercidas pelos gêneros selecionados numa unidade didática, elaborada para uma turma de $6^{\circ}$ Ano, numa escola pública municipal, juntamente com duas professoras em formação, num Mestrado Profissional em Letras (BEZERRA, 2015; GARCIA, 2015). Todos os gêneros elencados na figura foram selecionados como objetos de ensino, porém desempenham algumas funções didáticas diferenciadas. Nos dois círculos centralizados, estão dispostos os gêneros âncoras, diário fictício e autobiografia, os quais foram selecionados como produto intermediário e produto final, respectivamente. As atividades de práticas de linguagens, desenvolvidas ao longo da unidade didática, são realizadas de forma contextualizada em função da produção desses dois 
gêneros, que ganham maior relevância na sequência de atividades didáticas planejadas.

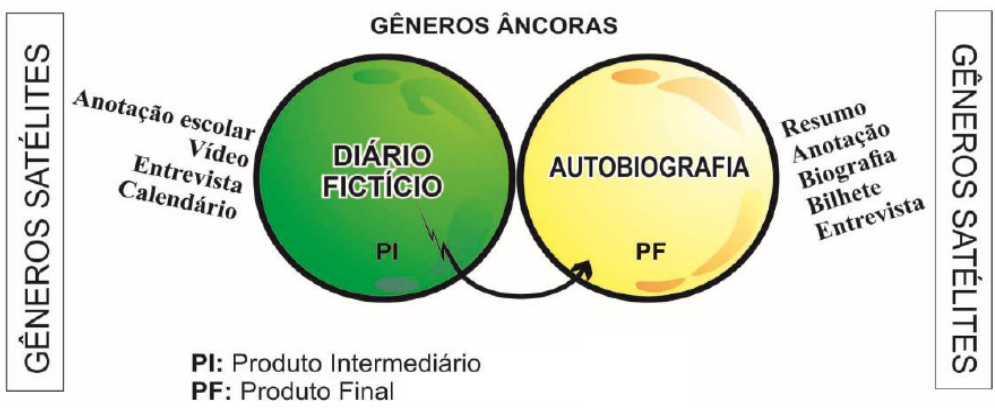

Figura 1: Gêneros na Unidade Didática.

Os gêneros localizados nas laterais da Figura 1 (anotação, anotação escolar, bilhete, biografia, calendário, entrevista, resumo, vídeo) são identificados como gêneros satélites. São responsáveis pela contextualização das atividades de leitura, escrita e análise linguística, necessárias para alcançar as etapas finais, quando são produzidos os gêneros âncoras. $\mathrm{O}$ trabalho com um gênero satélite, como a leitura de vídeos, pode se configurar como uma etapa prévia essencial para avançar na direção das atividades seguintes. Tal leitura é proposta para contribuir com a ampliação o repertório de conhecimento dos alunos sobre o assunto focalizado, que será aproveitado durante a operacionalização da unidade didática.

Quando comparo a proposta de unidade didática, apresentada neste artigo, com o projeto elaborado pelos alunos-mestre nos estágios, percebo de imediato a diferença nas funçóes didáticas exercidas pelos gêneros. Diferentemente da unidade didática, onde os gêneros estão articulados como elos de uma corrente, no projeto investigado, cada gênero é trabalhado isoladamente: as pequenas sequências de atividades se encerram no trabalho com cada gênero isoladamente.

Com o instrumento de ensino proposto, há um esforço em garantir o trabalho didático com o gênero o mais próximo do uso que dele é realizado no contexto interacional situado, mesmo que a escola, de alguma forma, 
funcione como espaço de ficção ${ }^{19}$. O uso realizado da unidade didática também é orientado por um modelo de ensino de gêneros, desenvolvido no âmbito da LSF, o qual fora traduzido para as pesquisas por mim orientadas como Circuito Curricular Mediado por Gênero - CCMG (cf. CALLAGHAN, KNAPP e NOBLE, 2014[1993]; MARTIN, 2012[1999]). Há outros modelos de ensino propostos no âmbito das pesquisas sistêmicofuncionais envolvendo o trabalho didático contextualizado por meio de gêneros, os quais foram adaptados às necessidades de diferentes projetos letramento, construídos a favor do empoderamento de grupos desprestigiados, especialmente no contexto australiano (cf. GOUVEIA, 2014; MARTIN, 2012[1999]; MARTIN; ROSE, 2005; SILVA, 2014; VEEL, 2006).

$\mathrm{Na}$ Figura 2, apresento a tradução da versão do CCMG assumida recentemente nas pesquisas mencionadas. A escolha do modelo foi motivada pela articulação possível entre o referido circuito e as práticas escolares de linguagem aqui focalizadas, conforme paradigma vigente para o ensino do português como língua materna, no território brasileiro. $\mathrm{O}$ circuito pode ser utilizado para fins pedagógicos, pelos professores da Educação Básica, de forma mais dinâmica, evitando-se o uso restrito da ferramenta a partir da LSF (cf. SILVA; ESPINDOLA, 2013). Conforme Callaghan, Knapp e Noble (2014[1993]), o circuito curricular é "uma tentativa de envolver os aprendizes em uma conscientização dos propósitos sociais, da estrutura textual e dos traços linguísticos em uma variedade de gêneros".

\footnotetext{
${ }^{19}$ Conforme Schneuwly e Dolz (2004, p. 76), na abordagem do interacionismo sociodiscursivo, "a particularidade da situação escolar reside no seguinte fato que torna a realidade bastante complexa: há um desdobramento que se opera em que o gênero não é mais instrumento de comunicação somente, mas é, ao mesmo tempo, objeto de ensino-aprendizagem. O aluno encontra-se, necessariamente, num espaço do 'como se', em que o gênero funda uma prática de linguagem que é, necessariamente, em parte, fictícia, uma vez que é instaurada com fins de aprendizagem" (itálico do original).
} 


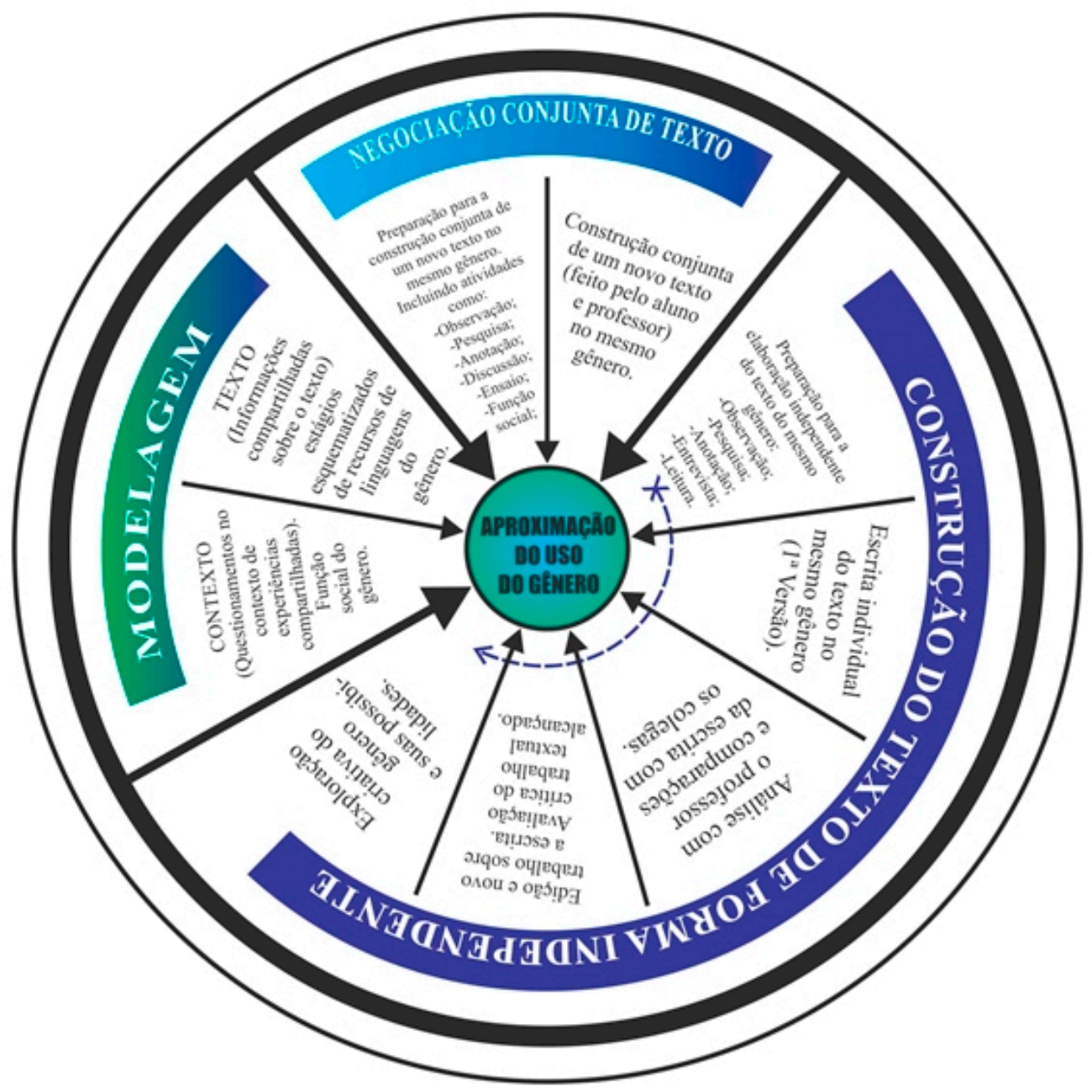

Figura 2: Circuito Curricular Mediado por Gênero. ${ }^{20}$

O CCMG é organizado em três etapas principais, orientadoras dos procedimentos didáticos a serem assumidos no planejamento e, consequentemente, nas aulas ministradas: Modelagem; Negociação conjunta de texto; e Construção do texto de forma independente. Quando a unidade didática é produzida atrelada ao CCMG, os gêneros satélites podem ser inseridos para realização das etapas distintas, que são orientadas em função

\footnotetext{
${ }^{20}$ Tradução realizada no grupo de pesquisa Práticas de Linguagens em Estágios Supervisionados - PLES (UFT/CNPq) a partir de Callaghan, Knapp e Noble (2014[1993]).
} 
dos gêneros âncoras. Por meio do circuito, as noções teóricas de contexto e de texto orientarão a ação docente. Ademais, conforme exposto no início deste artigo, na abordagem sistêmico-funcional da linguagem, o contexto social motiva as estabilizações textuais responsáveis pela configuração genérica. $\mathrm{Ou}$ seja, ao se focalizarem aspectos contextuais, não se perdem de vista as escolhas léxico-gramaticais, instanciadas nos textos de gênero.

Modelagem: no primeiro momento, o professor focalizará o Contexto sociocultural de circulação do gênero ensinado, envolvendo inclusive relaçôes de poder que atravessam as situaçôes de uso do gênero. A prática de leitura e escuta é responsável pela realização desse primeiro momento, que auxiliará o desenvolvimento do segundo momento, quando a materialidade textual passará a ser focalizada, mais especificamente a organização da estrutura esquemática do texto e escolhas léxico-gramaticais características da materialidade linguística realizada no gênero.

Negociação conjunta de texto: no primeiro momento, o contexto e o texto são focalizados conjuntamente. Junto com o professor, os alunos são levados a pesquisar sobre o gênero estudado, considerando as funções sociais desempenhadas por ele, organização da estrutura esquemática textual e usos léxico-gramaticais característicos. Para tanto, alunos e professor discutem sobre o assunto, tomam notas e fazem esquemas preparatórios para o exercício da escrita coletiva. Outros gêneros podem ser acionados para obtenção das informações pesquisadas. Principalmente, as práticas de leitura e de análise linguística são responsáveis pela realização desse primeiro momento, que desencadeará, no segundo momento, na prática de produção textual conjunta do gênero estudado.

Construção do texto de forma independente: esta etapa se assemelha à anterior, diferenciando-se pelo trabalho individual do aluno, afinal é esperado que a interação prévia tenha possibilitado a apropriação do conhecimento pelo aluno. No primeiro momento, individualmente, os alunos são levados a pesquisar sobre o gênero estudado, considerando as funções sociais desempenhadas por ele, organização da estrutura esquemática textual, assunto focalizado e escolhas léxico-gramaticais características. Tomam notas e fazem esquemas preparatórios para o exercício da escrita individual de um novo texto do mesmo gênero, que acontecerá no segundo momento, por meio da prática de produção textual. Principalmente, as práticas de leitura e análise linguística são responsáveis pela realização desse momento inicial da etapa. No terceiro momento, os textos produzidos são 
analisados com o auxílio do professor, resultando no encaminhamento para reescrita. As práticas de leitura e de análise linguística são responsáveis por essas últimas atividades, bem como dos dois momentos subsequentes. No quarto momento, o aluno reescreve e realiza uma avaliação crítica do texto produzido, o que, no quinto momento, resultará num exercício de reescrita com maior autonomia, explorando a criatividade no exercício da escrita, considerando o vasto horizonte de escolhas textual-discursivas motivadas pelo dinamismo da linguagem.

\section{Considerações finais}

Ao assumir a perspectiva indisciplinar da LA nesta investigação, eu também assumi o compromisso de apresentar uma análise crítica do trabalho didático de recontextualização dos gêneros para aulas de língua materna, desenvolvido por professores em formação inicial, matriculados em disciplinas de estágio supervisionado de uma Licenciatura em Letras. Conforme dito ainda na introdução deste artigo, por estarem às portas do local do exercício efetivo do magistério, escolas de ensino básico, acredito que o diagnóstico mostrado do trabalho desses alunos-mestre é revelador do alcance de teorias dos gêneros no contexto da prática profissional docente, bem como da demanda por uma formação profissional mais ousada.

Saber o que são gêneros ou descrevê-los e, até mesmo, identificá-los não garante um planejamento didático promissor. A esse respeito, faço referência à atividade didática proposta com o gênero conto, no projeto pedagógico investigado. $\mathrm{O}$ conhecimento da teoria acadêmica não resulta, necessariamente, no sucesso do trabalho docente na escola básica. Mas, nas licenciaturas, a atitude de muitos formadores parece revelar exatamente o pensamento oposto. Neste parágrafo, parece que não estou dizendo nenhuma novidade, mas foi necessário mostrar evidências do resultado do uso de teorias acadêmicas pouco articuladas à prática profissional do professor no espaço de atuação profissional.

Afirmo com muita certeza que a teoria acadêmica precisa ser gerada mais nas bases da sociedade, no próprio local de onde emergem as demandas sociais e as vozes mal ouvidas. As teorias não podem continuar chegando às escolas a posteriori, para realização da conhecida aplicação teórica. Os resultados dessa prática são velhos conhecidos, algumas evidências foram, inclusive, mostradas aqui, mas há quem ainda prefira continuar ignorando os resultados indigestos. 
A ousadia na instrução dos professores está na geração do conhecimento com esses profissionais, nas próprias situações de formação (inicial ou em serviço) em que estão inseridos os linguistas aplicados. Por estar em constante contato com o contexto escolar, ninguém melhor que os professores para auxiliar os pesquisadores na elaboração de propostas ou modelos de ensino que, realmente, possam contribuir com o trabalho realizado nas salas de aula da Educação Básica. Finalmente, com essas breves consideraçôes finais, eu tenho a esperança de também ter sintetizado aqui um pouco das atribuições da Linguística Aplicada, delas os verdadeiros linguistas aplicados não deveriam escapar ${ }^{21}$.

\section{Referências}

BAZERMAN, C. Gênero, agência e escrita. In: HOFFNAGEL, J. C.; DIONISIO, A. P. (Orgs.). São Paulo: Editora Cortez, 2006.

BEZERRA, S. O. X. Letramentos orientados por circuito curricular mediado por gêneros: práticas de escrita e de análise linguística em aulas de língua portuguesa. 2015. 204 f. Dissertação (Mestrado Profissional em Letras - ProfLetras) Universidade Federal do Tocantins, Araguaína, 2015.

BRASIL. Orientaçôes Curriculares para o Ensino Médio: Linguagem, códigos e suas tecnologias. Brasília: Ministério da Educação/Secretaria de Educação básica, 2006. BRASIL Parâmetros Curriculares Nacionais. Língua portuguesa: Ensino Médio. Brasília: Ministério da Educação. 2000.

BRASIL. Parâmetros Curriculares Nacionais. Língua Portuguesa: Ensino Fundamental II. Brasília: Secretaria de Educação Fundamental (SEEF)/MEC, 1998.

CALLAGHAN, M.; KNAPP, P.; NOBLE, G. Genre in practice. In: COPE, B.; KALANTZIS, M. (Eds.). The powers of literacy: a genre approach to teaching writing. London: Falmer Press, 1993. p. 180-189. Disponível em: http:// newlearningonline.com/literacies/chapter-5/callaghan-knapp-and-noble-on-thegenre-curriculum-cycle-or-wheel. Acesso em: 26 nov. 2014.

\footnotetext{
${ }^{21}$ Agradeço ao Centro Interdisciplinar de Memória dos Estágios Supervisionados das Licenciaturas - CIMES (UFT) pela disponibilização dos documentos para análise. Agradeço ainda à dupla de estágio pelo auxílio durante a produção desta pesquisa e pela leitura realizada do artigo. Por fim, também preciso expressar meus agradecimentos a Adair Vieira Gonçalves, a Lívia Chaves de Melo e aos pareceristas anônimos deste artigo pela leitura crítica realizada deste texto. A responsabilidade pelo manuscrito, porém, é completamente minha.
} 
CHEVALLARD, Y. La transposición didáctica: del saber sabio al saber enseñado. Buenos Aires: Aique Grupo Editor. 2005.

CHRISTIE, F. Literacy teaching and current debates over reading. In: WHITTAKER, R.; O’DONNELL, M.; McCABE, A. (Eds.). Language and literacy: functional approaches. London/New York: Continuum, $\mathrm{p}$. 45-65, 2006.

COSTA, S. R. Dicionário de gêneros textuais. Belo Horizonte: Autêntica, 2008.

BAKHTIN, M. Estética da criação verbal. $3^{\mathrm{a}}$ ed. São Paulo: Martins Fontes, 2000.

EGGINS, S. An introduction to systemic functional linguistics. $2^{\mathrm{a}} \mathrm{ed}$. London: Continuum, 2004.

EGGINS, S.; MARTIN, J. R. Genres and registers of discourse. In: DIJK, T. A. V. (Org.). Discourse as structure and process. London: SAGE Publications Ltd, v. 1, p. 230-256, 1997.

GARCIA, V. B. B. R. Transformaçôes em aulas de leitura e análise linguística: percursos de professoras. 2015. $200 \mathrm{f}$. . Dissertação (Mestrado Profissional em Letras - ProfLetras) - Universidade Federal do Tocantins, Araguaína, 2015. GOUVEIA, C. A. M. Compreensão leitura como base instrumental do ensino da produção escrita. In: SILVA, W. R.; SANTOS, J. S.; MELO, M. A. (Orgs.). Pesquisas em língua (gem) e demandas do ensino básico. Campinas: Pontes Editorial, p. 203-231,

2014. GUARESCHI, P. Empoderamento. In: STRECK, D. R.; REDIN, E.; ZITKOSKI, J. J. (Orgs.). Dicionário Paulo Freire. Belo Horizonte: Autêntica, p. 165-166, 2008.

KLEIMAN, A. B. O processo de aculturação pela escrita: ensino da forma ou aprendizagem da função. In: KLEIMAN, A. B.; SIGNORINI, I. (Orgs.). $O$ ensino e a formação do professor: alfabetização de jovens e adultos. Porto Alegre: Artmed, p. 223-243, 2000. MARCUSCHI, L. A. Produção textual, análise de gêneros e compreensão. São Paulo: Parábola Editorial, 2008.

MARTIN, J. R. Mentoring Semogenesis: “Genre-Based” Literacy Pedagogy. In: ZHENHUA, W. (Ed.). Language in Education. v. 7. Shanghai: Shanghai Jiao Tong University Press, p. 224-254, 2012[1999]. 
MARTIN, J. R.; ROSE, D. Designing literacy pedagogy: scaffolding democracy in the classroom. In: HASAN, R.; MATTHIESSEN, C.; WEBSTER, J. J. (Eds.). Continuing discourse on language: a functional perspective. London/Oakville: Equinox, v. 1, p. 251-280, 2005.

MELO, L. C.; GONÇALVES, A. V.; SILVA, W. R. Escrita acadêmica na escrita reflexiva profissional: citaçōes de literatura científica em relatórios de estágio supervisionado. Bakhtiniana: Revista de Estudos do Discurso, v. 8, n. 1, p. 95-119, 2013.

MONTEIRO, K. C. S. Proposta didática com alunos paraenses em processo de alfabetização a partir de um circuito curricular mediado por gêneros. Dissertação em andamento (Mestrado Profissional em Letras - ProfLetras) - Universidade Federal do Tocantins, Araguaína, 2015.

OLIVEIRA, M. do S.; TINOCO, G. A.; SANTOS, I. B. de A. Projetos de letramento e formação de professores de língua materna. Natal: EDUFRN, 2011.

ROJO, R. Materiais didáticos no ensino de línguas. In: MOITA LOPES, L. (Org.). Linguística Aplicada na modernidade recente: Festschirft para Antonieta Celani. São Paulo: Parábola Editorial/Cultura Inglesa, p. 163-195, 20014.

ROJO, R. Os gêneros do discurso e gêneros textuais: questôes teóricas e aplicadas. In: MEURER, J. L.; BONINI, A.; MOTTA-ROTH, D. (Orgs.). Gêneros: teorias, métodos, debates. São Paulo: Parábola Editorial, p. 184-207, 2005.

DOLZ , J.; SCHNEUWLY, B. Os gêneros escolares - das práticas de linguagem aos objetos de ensino. In: ROJO, R.; CORDEIRO, G. (Orgs.). Gêneros orais e escritos na escola. Campinas: Mercado de Letras, p. 71-91, 2004.

SIGNORINI, I. Apresentação. In: SIGNORINI, I (Org.). Significados da inovação no ensino de língua portuguesa e na formação de professores. Campinas: Mercado de Letras, p. 07-15, 2007.

SIGNORINI, I. Prefácio. In: SIGNORINI, I (Org.). Gêneros catalisadores: letramento \& formação do professor. São Paulo: Parábola Editorial, p. 7-16, 2006. SILVA, E. C. M. Leitura e produção de gêneros textuais na escola. In: SILVA, W. R.; SANTOS, J. S.; MELO, M. A. (Orgs.). Pesquisas em lingua(gem) e demandas do ensino básico. Campinas: Pontes Editorial, p. 233-260,2014.

SILVA, W. R. Reflexão pela escrita no estágio supervisionado da licenciatura: pesquisa em Linguística Aplicada. Campinas: Pontes Editores, $2014 \mathrm{a}$.

SILVA, W. R. Considerações sobre contexto de cultura na Linguística SistêmicoFuncional. In: Anais do XVII Congresso Internacional da Associação de Linguística e Filologia da América Latina - ALFAL, 2014. Estudos Linguísticos e Filológicos. João Pessoa: Idéia, p. 1991-2003, 2014 b. 
SILVA, W. R. Escrita do gênero relatório de estágio supervisionado na formação inicial do professor brasileiro. Revista Brasileira de Linguistica Aplicada. Belo Horizonte: UFMG/ALAB, v. 13, n. 1, p. 171-195, 2013.

SILVA, W. R. Proposta de análise textual-discursiva do gênero relatório de estágio supervisionado. DELTA. Documentação de Estudos em Linguística Teórica e Aplicada (PUCSP. Impresso), v. 28, n. 2, p. 281-305, 2012 a.

SILVA, W. R. Gêneros textuais em aulas de Língua Portuguesa no Ensino Médio brasileiro. Linguagem \& Ensino. Pelotas: UCPel. v. 15, n. 2, p. 387-418, 2012 b.

SILVA, W. R. Construção da superação do fracasso do ensino de Língua Portuguesa em diretrizes curriculares. In: SIGNORINI, I; FIAD, R. S. (Orgs.). Ensino de língua: das reformas, das inquietações e dos desafios. Belo Horizonte: UFMG, p. 83-105, 2012c.

SILVA, W. R. Estudo da gramática no texto: demandas para o ensino e a formação do professor de língua materna. Maringá: Eduem, 2011.

SILVA, W. R. Algumas contribuições da Linguística Aplicada para o ensino de escrita em aulas de língua materna no Brasil. Investigaçôes: Linguística e Teoria Literária. Recife: UFPE, v. 22, n. 2, p. 135-160, 2009 a.

SILVA, W. R. Seleção textual no ensino interdisciplinar por projeto. Revista Brasileira de Linguística Aplicada. Belo Horizonte: UFMG, v. 9, n. 1, p. 17-39, 2009.

SILVA, W. R.; DINIZ. Estágio supervisionado obrigatório das licenciaturas como contexto de pesquisa das licenciaturas. Trabalhos em Linguística Aplicada. Campinas: UNICAMP, v. 53, n. 2, p. 333-355, 2014.

SILVA, W. R. ; ESPINDOLA, E. Afinal, o que é gênero textual na Linguística Sistêmico-Funcional. Revista da ANPOLL. v. 1, n. 34, p. 259-307, 2013.

SILVA, W. R.; MELO, L. C. Teoria acadêmica e prática docente em referencial curricular. In: SILVA, W. R; MELO, L. C. (Orgs.). Pesquisa \& ensino de língua materna e literatura: diálogos entre formador e professor. Campinas: Mercado de Letras, p. 37-62, 2009.

SILVA, W. R.; et al. Linguística Sistêmico-Funcional na sala de aula: práticas de leitura e análise linguística. Araguaína: Universidade Federal do Tocantins, 2015. (inédito) STREET, B. V. Letramentos sociais: abordagens críticas do letramento no desenvolvimento, na etnografia e na educação. Tradução Marcos Bagno. São Paulo: Parábola Editorial, 2014.

VEEL, R. The Write it Right Project - Linguistic modelling of secondary school and the workplace. In: WHITTAKER, R.; O'DONNELL, M.; McCABE, A. (Eds.). Language and literacy: functional approaches. London/New York: Continuum, p. 66-92, 2006. 


\section{Anexo}

\section{PROCURA-SE!}

Os beija-flores ou colibris estão entre as menores aves do mundo e são as únicas capazes de ficar voando no mesmo lugar, como um helicóptero, ou de voar para trás. Para isso, porém, as suas pequenas asas precisam movimentar-se muito depressa, o que gasta muita energia. Assim, eles precisam se alimentar bastante, e algumas espécies podem comer em um único dia até oito vezes o seu próprio peso. Uau!

O Balança-Rabo-Canela é um beija-flor pequeno que pesa apenas nove gramas e só existe no brasil. Ele tem as costas esverdeadas e a parte de baixo do corpo na cor canela, com um tom mais escuro na garganta. As penas da cauda, por sua vez, são de cor bronze e têm as pontas brancas. A ave possui ainda uma fina listra branca em cima e embaixo dos olhos.

Assim como os outros beija-flores, o Balança-Rabo-Canela geralmente se alimenta de pequenos insetos, aranha e néctar, um líquido doce produzido pelas flores. Para sugá-lo, essas aves têm uma língua com ponta dupla, que forma dois pequenos canudos.

É comum os beija-flores ficarem com os grãos de pólen das flores grudados nas penas e no bico depois de sugarem o néctar. Assim, acabam levando-os de uma flor a outra, à medida que seguem seu caminho. Como as flores precisam do pólen para produzir sementes, os beija-flores, sem querer, ajudam-nas ao fazer esse transporte e acabam beneficiados também, afinal, o néctar das flores é um dos seus alimentos.

Os beija-flores enxergam muito bem, e muitas flores possuem cores fortes, como vermelho ou laranja, para atraírem a sua atenção. Embora muito pequenas, essas aves são muito valentes e sabem defender seus recursos, como as flores que utilizam para se alimentar. Assim, alguns machos podem até expulsar as fêmeas da sua própria espécie caso elas cheguem perto da comida. Na luta pela sobrevivência parece não haver espaço para gentileza, machos e fêmeas geralmente se juntam apenas na época da reprodução.

O Balança-Rabo-Canela coloca seus ovos de setembro a fevereiro e choca-os durante 15 dias. A fêmea é quem constrói o ninho e também cuida dos filhotes por quase um mês após o nascimento para que eles consigam sobreviver sozinhos.

O pequeno Balança-Rabo-Canela está ameaçado de extinção por conta da destruição do ambiente onde vive, ou seja, do seu habitat. As matas, que 
servem de lar para essa ave, estão sendo destruídas de maneira acelerada para a criação de animais, o cultivo de alimentos, a instalação de indústrias e pelo crescimento das cidades. Portanto, precisamos preservá-las para que esse belo beija-flor não desapareça para sempre.

Fonseca, Lorena c.n; Alves, Maria Alice. Procura-se! Ciência hoje para crianças, Rio de Janeiro, n.159, jul. 2005.

Fonte: http://profhelena4e5ano.blogspot.com.br/2010/11/procura-se.html (acesso em 16/08/2014) ${ }^{22}$

${ }^{22}$ Essas fontes do texto aqui apresentadas foram acrescentadas por mim, pois, no texto anexado ao relatório, não havia identificação alguma de fonte ou de autoria textual.

Data de submissão: 21/08/2014. Data de aprovação: 04/12/2014. 
